\title{
A Grace-Based Leadership Approach to Managing Gen A in the Digital Age
}

http://doi.org/10.21272/bel.3(3).88-98.2019

\section{Yu Sing Ong}

Dr, Professor, ELM Graduate School, HELP University, Malaysia

\begin{abstract}
This paper discusses a grace-based approach in managing the Gen A workforce in the digital age. It is a philosophical approach that covers grace, compassion, ethics, empowerment, and trust. On the basis of the conducted research the author proposes three theoretical lenses, organizational management, religious, and philosophical hybridism to conceptualize the grace-based leadership model that addresses the deterioration in ethical business behavior which gives rise to fraud, corruption, and loss of integrity. Specifically, this paper highlights the humanism aspect of organizations from the perspective of established philosophies and religions such as I Ching, Confucianism, Buddhism, Islam, and Hinduism. The methodological basis for this paper is found within the theological, philosophical, psychological, and managerial fields. This study uses both interpretative phenomenological and hermeneutics approaches to interpret and understand the divine and classical texts of I Ching, Confucian Analects, Sutras, Quran, and Bhagavad Gita. The main hypothesis of the research is the idea that qualitative inquiries in management and leadership contexts can be enriched through linkages to the study of interpretative phenomenology and hermeneutics. The practical significance of this paper lies in the potential for developing a theoretical framework in humanistic leadership. According to the findings, this paper concludes that the deciding factor for an organization's success in the digital era will be its ability to evolve its corporate culture to not only take advantage of emerging technologies but also to embrace the principle of humanism in the workplace.
\end{abstract}

Keywords: Gen A, grace-based leadership, I Ching, Islam, Confucian, Buddhism, Hinduism, phenomenology, hermeneutics, grace-based approach.

JEL Classification: M100, B00, Z10, Z12.

Cite as: Yu, S.O. (2019). A Grace-Based Leadership Approach to Managing Gen A in the Digital Age. Business Ethics and Leadership, 3(3), 88-98. http://doi.org/10.21272/bel.3(3).88-98.2019.

(C) The Author, 2019. This article is published with open access at Sumy State University.

\section{Introduction}

Ethics is a process by which individuals and society evaluate their actions from the perspective of moral principles and values (Hurley, 1972). In business, it involves a series of behaviors that adhere to the values held by the managers and customers (Bartlett and Ghoshal, 1994). By holding on to values, society knows the principles that define acceptable behavior. These values may change as individuals become more knowledgeable due to their exposure to new technologies. The internet has given them access to a wealth of information which was previously available to a small group of individuals and organizations.

The new wave of technologies such as social media, artificial intelligence, machine learning, and Internet-ofThings is transforming the way we work and live. In the digital age, a new generation of workers who are competent with technologies emerge. These are known as the Generation A (analytics generation) workforce who brings new expectations to the workplace. They transverse across generations and are differentiated not by their age, but by their digital competencies. They are tech-savvy with an inherent understanding of digital technologies. They include both digital natives and digital immigrants - those who readily adopt digital technologies. They incorporate analytics into their thought process more so than others (Yu, 2019).

In the digital age, we need qualities such as curiosity, adaptability, agility, and empathy, from both the business leaders and employees. The widespread use of technologies and the shift from cognitive skills to character qualities represent a paradigm shift in the way businesses are managed. Business leaders should focus more towards purpose and values instead of profits, autonomy instead of hierarchy, and empathy instead of apathy. They should connect to a higher purpose and engage their employees according to that purpose. New technologies can upset traditional power balances as those with information will dominate and create ramifications in the digital world. 


\section{Ching}

The I Ching is an ancient divination text and one of the oldest Chinese classic texts. It serves as a guide to tapping the wisdom of the unconscious mind and addresses the practical world of decision making. It prompts one to magnify one's intuitive inner wisdom. Through increased self-awareness, one is in a better position to practice self-reflection to discover one's full potential. Leaders who reflect on their own behaviour tend to ensure that their behaviour always aligns with their innermost values. Decisions made must be based on an integrated understanding of one's self and the environment.

In a VUCA (volatile, uncertain, complex and ambiguous) environment, leaders have to adopt agile approaches to address the radically changing business models caused by disruptive technologies. The changing expectations of employees, consumers, business partners, and society have forced organizations to adapt to new strategies quickly. The answers to questions and advice on many of today's business problems can be obtained by referring to the text accompanying one of the 64 hexagrams. For the purpose of this paper, the author will focus on Hexagrams 1,2, 4, 6, and 11. A detailed description of I Ching with interpretations of the 64 hexagrams is available in his book Humaninsing Gen A Leadership: Inspirations from I Ching (Yu, 2019).

Hexagram 1 represents pureness and wholesome. It stands for power, light, strength, activity, male, father, and sovereign. Its image is heaven and represents the creative action of the Creator. It describes an accumulation of energy and the way to channel the energy in the proper direction. The Way of the Creative works through change and transformation, so that things comes into permanent accord with the great Harmony. In relation to the world, it represents the creativity of man. Creativity sublimes success. A superior man makes himself successful and strong through perseverance. Success is closely linked to morals and wisdom while perseverance is associated with time.

The inspiration for a leader is to develop positive traits such as the ability to build strong relationships with others, exhibit confidence, possess the courage to confront challenges, and willing to think outside the box. He must be digitally savvy as he represents the face of the organization. To get employees on-board the digital bandwagon, he has to explain to his people how they will fit into a new digital-oriented culture. His employees will be looking to him as a role model on how they could upgrade their digital skills.

Leaders in the new digital era have to realize that possessing soft skills make a difference to the bottom line. The values that they embrace and the beliefs that they hold are transmitted throughout the team. They are responsible for their words, behaviours, and actions. The author proposes a digital humanistic leadership model comprising three elements - people development, organization growth and value management (Fig. 1).

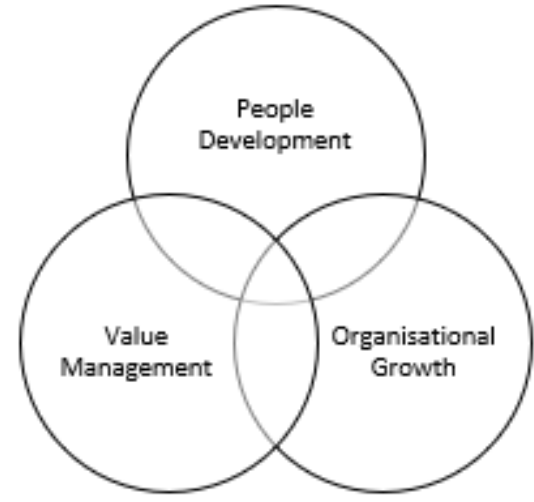

Source: Elaborated by the author

Figure 1. Humanistic Leadership Model

Hexagram 2 symbolizes earth, nature, field, receptiveness, compliance, acquiescence, docility, and feminineness. The earth is receptive and sustains all life. Similarly, the virtuous person possesses good values such as generosity and tolerance. It represents what is great and correct.

Digital leaders must possess the ability to perceive and understand the nature of interactions within the enterprise as a system. The dynamics of the interactions often add to the complexity of management and control. According to the Viable System Approach (VSA), the long term survival and success of a system depends on effective interactions among the components within the system. The VSA is a methodological approach that is useful for the comprehension of complex phenomena involving individuals, business and society (Golinelli et al., 2009; Barile and Polese, 2010). 
ISSN (online) - 2520-6311; ISSN (print) - 2520-6761

Developing customer insights with analytical tools not only helps companies better understand their customers but also provides valuable information for new product innovation and brand strategies. Social media has empowered consumers and is shifting the power balance from brands to the consumers (Fournier and Avery, 2011). Brands must adapt to the culture on the social platform which they are active on. Consumers are no longer passive; they are actively in control over information creating new content regarding the brand. Similarly, social platforms must be receptive to consumers' behaviors in order to build trust as consumers' trust may be reduced if their comments are deleted (Khong et al., 2013).

Hexagram 4 represents a spring which encounters a mountain in its path. The mountain is strong, but the spring flowing out of it seeks its path. The path has many obstacles. The main obstacle a person may come across is his ignorance. While he may be educated, he lacks certain knowledge and experience to handle a particular situation.

While top management makes the key decisions, they understand that they cannot let their ego rule the business. A leader should accept the fact that he may not be an expert in new technologies. He adopts collaborative leadership to get effective results across internal and external organizational boundaries. He recognizes that power is greatest in a collective team and acknowledges the differences in competencies among the team members. The leader must be willing to learn and display the right attitude to lead his team and create an environment of trust among team members. Improved team collaboration will lead to improved team performance (Peters and Manz, 2007).

Hexagram 6 relates to conflict. Though one's intention is sincere, he may meet with opposition. To prevent conflict, it is necessary to plan ahead and delimitate the role and responsibility of everyone involved. Contention should not be prolonged and should be cautiously stopped. A retreat is no disgrace but a show of inner strength. An effective leader is a mediator who finds a solution to the parties in conflict.

The traditional corporate hierarchy has given way to a decentralized network of teams that are empowered to do their work and get closer to their customers. The leader creates and sustains an inspiring vision and implements this vision together with his team. The greater his vision, the more followers it has the potential to attract. Possessing the interpersonal skills to maintain the sustainability and development of the organization will differentiate him from less effective leaders (Luthra and Dahiya, 2015).

Hexagram 11 indicates that everything is in harmony and the leader is on the right path to success. By carefully managing conflict and chaos, he ensures peace and harmony of the people below him. He furthers and regulates the gifts of heaven and earth and gives aid to the people. Wealth is used to support his designs and to elevate his followers. Because of his willingness to share, his people will pledge allegiance to him.

Leaders should design an intelligent workplace where information will be available for everyone. Offering tools that integrate knowledge into the workflows of employees can boost productivity and improve performance while reducing the pressure to pull employees away from their tasks for training. The concept of a learning organization involves notions like shared vision, learning, continuous improvement and making tacit knowledge explicit. The notion of learning is, however, limited as it does not specifically detail how work is organized in a learning organization (Poell et al., 1997). For organizational learning to be effective, appropriate measures must be implemented to enable support, share and reward the use of what is learned. The role of a leader in a learning organization is that of a designer, facilitator, and mentor (Senge, 2006).

\section{Confucianism}

Confucius' philosophy focussed on moral character and ethics which encompass Five Constants or $w u$ chang. They are:

1. Ren-humaneness, benevolence;

2. $Y i$ - righteousness, justice;

3. $L i$ - proper rite;

4. Zhi-knowledge, wisdom;

5. Xin - integrity.

Describing ren, Confucius advised "not to do to others as you would not wish done to yourself". He believed that man is kind and good by nature and should not seek wealth and status at the expense of humanity.

Facing saving is an important Chinese business concept which could be traced back to Confucius. Lian (face) reflects one's standing in public. Criticism from another party to cause one to lose face may jeopardize the business relationship between the parties. 
Illustrating the broader application of $l i$, Confucius included broad topics such as learning, titles, and governance. $L i$ regulates human interactions and etiquette.

Confucius believed that education should be provided to all without any discrimination. Education will make a difference in a person's character. One of the most important contributions of Confucius is that he advocated that all humans are equal and of one class.

Much of Confucius ideology could be applicable in modern-day management practices.

Confucius said:

1) "Success depends upon previous preparation, and without such preparation there is sure to be failure".

Businesses have to be sufficiently prepared to face the challenges in the global environment. Managers have to constantly conduct scenario planning exercises to ensure that they are adequately prepared for any downturns.

2) "If you think in terms of a year, plant a seed; if in terms of ten years, plant trees; if in terms of 100 years, teach the people".

Confucius highlighted the importance of formulating strategies to develop a competitive advantage in the business. This strategic plan is to be put into action through proper planning and management.

3) "Better a diamond with a flaw than a pebble without".

Managers should value righteousness and ethical principles above profits. Their business behaviours should be governed by high moral and ethical principles.

Mencius, a well-known Confucian philosopher, is highly regarded for his views on the virtues, ethical cultivation, and goodness of human nature. His contribution to modern-day management is in the area of participative management and employee autonomy. He stressed that leaders should also learn from their subordinates.

Mencius said:

"Today there are many states, all equal in size and virtue, none being able to dominate the others. This is simply because the rulers are given to employing those, they can teach rather than those from whom they can learn".

Mencius also taught the need for a good interpersonal relationship between superior and subordinate. Managers have to earn the support and respect of their subordinates if they wish to achieve greater goals. He saw a good leader as possessing three main qualities: benevolence, servant-leadership, and humanism (Fig 2).

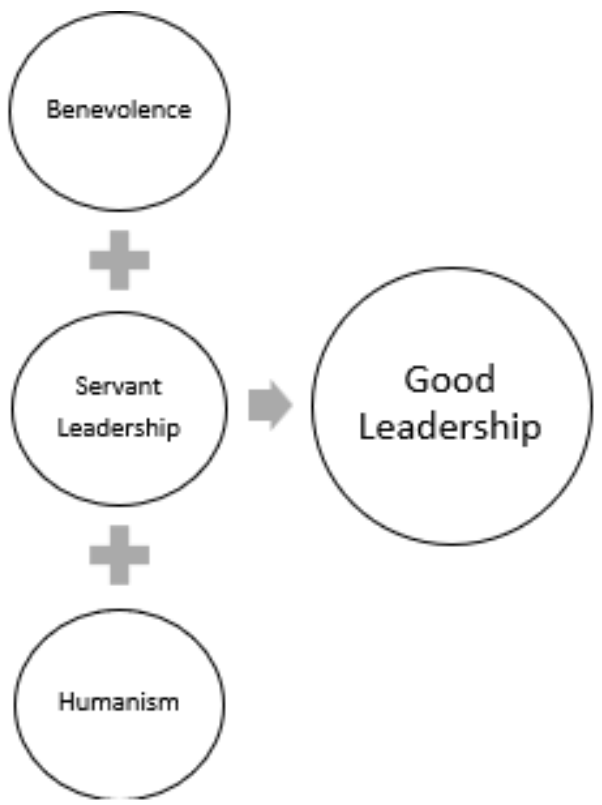

Source: Elaborated by the author

Figure 2. Mencius' view of a good leader

\section{Buddhism}

Buddhism originated from India and shares many of the Hindu concepts of karma and samsara. The founder was a young prince from Nepal named Siddhartha Gautama. He left a life of luxury to experience human 
Business Ethics and Leadership, Volume 3, Issue 3, 2019

ISSN (online) - 2520-6311; ISSN (print) - 2520-6761

suffering. After attaining enlightenment, he was known as Buddha and spread his religious teachings of Buddhism.

According to Hinduism, karma governs the universe and the beings within it. Some beings are being elevated to the upper planetary systems while others are being lowered into the lower planetary systems. The sum total of one's good and bad deeds will determine how one will be rewarded or punished in the next life. The belief of samara or reincarnation means that there is a never-ending cycle of birth, death, and rebirth.

Buddha reminded us that change is everywhere, and nothing is permanent. Managers should embrace change and detach from the dogmas of old management styles.

Buddhism has its practical application in today’s business world (Figure 3). Its focus on communal harmony, ethics, teamwork, learning and development, and employers' duties are important in shaping modern management practices in the Orient.

Buddhism also advocates constant learning and development. The development of others is equally important as the development of self.

Buddha said:

"Believe nothing merely because you have been told it. Do not believe what your teacher tells you merely out of respect for the teacher. But whatever, after due examination and analysis, you find to be kind, conducive to the good, the benefit, the welfare of all beings - that doctrine believe and cling to, and take it as your guide".

Buddha in his advice to Sigalaka Sutta enumerates five ways an employer should treat his employees:

1) Assigning work according to their strengths - The work assigned should be according to their mental and physical strengths. Bosses should not take advantage of their employees.

2) Giving them food and wages - Pay them accordingly to their efforts.

3) Tending them in sickness - Grant them medical leave when they are unwell.

4) Sharing with them unusual delicacies - Reward them with bonuses or other material means.

5) Granting leave at suitable times - Grant them time off for their personal matters.

Teamwork is an important concept in Buddhism. Personal sacrifice for the benefit of the team helps the organization to pull through in times of crisis. Buddha said:

"Whoever offers sacrifice, or whoever gets others to do so - all these are following a course of merit benefiting many others."

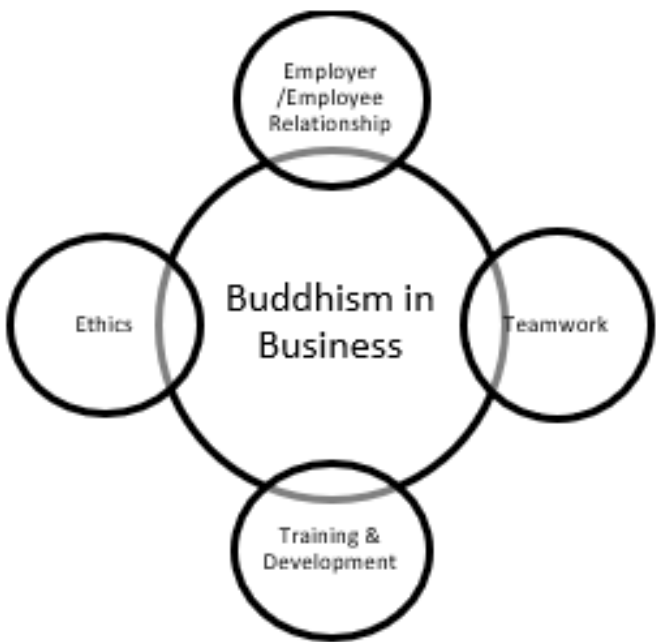

Source: Elaborated by the author

Figure 3. Buddhism in Business

\section{Islam}

There are many common features between Western management and Islamic management. Yet, there are many differences between the two in that Islamic management focuses more on principles guided by the Quran and hadiths. Profit is not the main objective for Islamic organizations, but it is seen as a reward from the Creator. Islam's approach to management can be defined as worshipping Allah and acting as His 
vicegerents on Earth. Islamic management is based on values, ethics, and morals. It is desirable for managers to develop their managerial skills according to Islamic principles. In Islam, a leadership and management position is responsibility, commitment, and guidance, not power, glory or position.

Every Muslim is accountable to Allah for his or her actions. He has to allocate the time for solitude through prayers for the purpose of spiritual growth. A real Muslim is one who is trustworthy and a person of integrity. He will admit when he is wrong and seek forgiveness when necessary. The introduction of spirituality in the workplace is gaining popularity. A spiritual organization is characterized as having a strong sense of purpose, focus on individual development, employee empowerment, and tolerance. It embraces spiritual values such as integrity, honesty, accountability, trustworthiness, respect, and justice. Key outcomes include higher morale, greater job satisfaction, improving productivity and increase profitability. The qualities of an ideal Islamic employee such as sincerity (ikhlas), humanness, organized, determined, hardworking and good conduct are highlighted as important values to an organization. At the same time, a leader must display qualities such as leadership, trust, confidence, humility, responsibility, and open-mindedness to gain the respect of his followers.

Religion and spirituality have a great relevance and relationship in management and organizational life. Companies have to embrace the religious diversity of their employees. Their religion and spirituality define who they are. How managers deal with their employees will affect organizational issues such as productivity, turnover, employee satisfaction, team spirit, etc. In Islam, followers are obliged to follow their leaders' instructions as long as the leaders are acting honorably. Leaders are normally appointed by the group and play the role of God's vicegerents. Leaders inspire and coach followers in an effort to achieve a shared vision (Alvarez \& Svejenova, 2005).

A leader has to possess a high standard of character. He has to be a role model for his followers. Trust (amanah), responsibility (taklif) and accountability (mas'uliyyah) are qualities that a leader must have. Purification of the mind in Islam is known as tazkiyyah. Human mind is prone to corruption. It is the responsibility of every believer to avoid undesirable behavior and to recognize that worldly desires can pollute the mind and corrupt the soul. An Islamic leader is one who should be selfless and respect and honor all human beings, regardless of their religion, race, color, sex, status, profession, etc.

The concept of servant leadership has always been part of Islam. Muslim leaders need to have the right intention (niyyah) to help those around him to succeed. Servant-leaders foster collaboration by serving the community. They place themselves in the shoes of their followers and doing what they asked their followers to do. They focus primarily on the growth and well-being of the followers and communities to which they belong (Fig. 4).

Servant leaders are committed to building the community. This was shown by the Prophet (pbuh) when he called for the establishment of a community upon his arrival in Medina. The Prophet (pbuh) also recognized the importance of education and knowledge as the necessary ingredients for building community and sustaining the growth of the community.

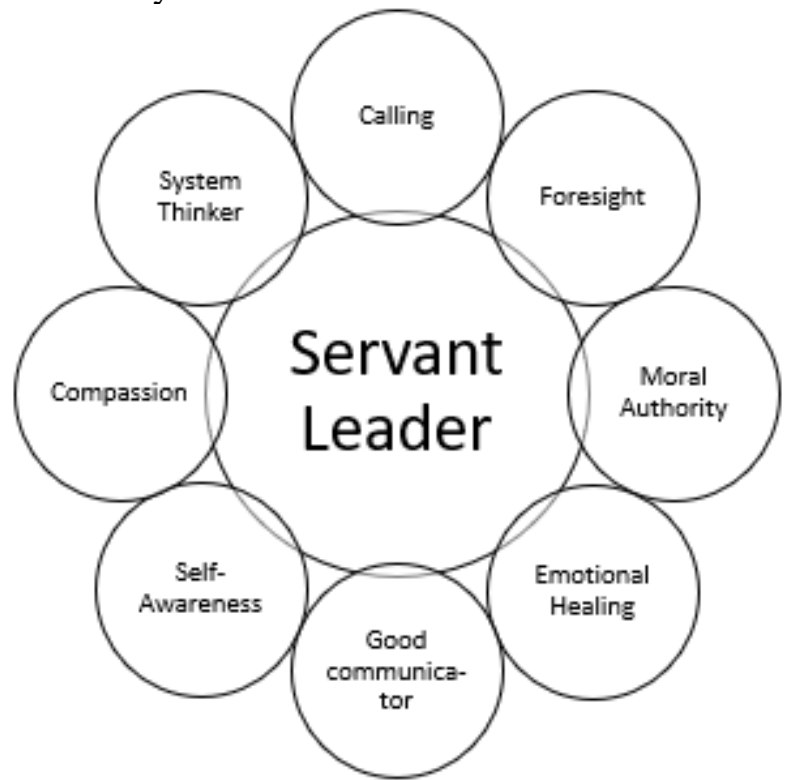




\section{Hinduism}

The Bhagavad Gita is a Sanskrit scripture in Hinduism. It contains 700 verses and forms part of the larger scriptural epic known as Mahabharata. It details Lord Krishna's advice to the warrior, Arjuna. It is a quintessential manual of Self-awareness and Self-knowledge. The significance of Bhagavad Gita is reflected in its status as a Shruti (revealed) text of divine provenance. It teaches karma yoga (path of selfless action), bhakti yoga (path of devotion) and jnana yoga (path of self-knowledge). Many leadership lessons are embedded within Bhagavad Gita:

a) Leaders must be aware of self and the environment;

b) Leaders should embrace challenges rather than avoiding them;

c) Leaders who exercise compassion and selfless service will earn the respect of followers;

d) Good character is essential for effective leadership.

Bhagavad Gita recommends meditation to understand our true self. Jivanmukti (realizing our true self) is essential for maintaining the balance of the self, mind, and body through the three gunas (virtues, attributes) in Hindu Samkhya philosophy: sattva (goodness, harmonious), rajas (passion, active), and tamas (darkness, destruction). The three gunas are present in every human being but in different proportions and in different contexts. The balance of gunas can change in response to changes in internal and external influences. An intelligent leader is able to control his mind effectively, and not let the mind be controlled by the senses.

In addition, the Bhagavad Gita noted that three specific disciplines are required for effective leadership: the discipline of learning, the discipline of proper communication, and the discipline of equanimity. The last discipline calls for composure and not lose the balance of the mind in times of crisis. The leader neither rejoices upon achieving something pleasant nor laments upon something unpleasant.

The eighteenth chapter of the Bhagavad Gita covers leadership renunciation. The effective leader renounces selfish desire, arrogance, and inequality. The concept of leadership renunciation is similar to servant leadership. Leaders who act without selfish interest will be able to rally their followers. Those who expound the values and virtues of Bhagavad Gita will have a greater chance of motivating their followers spiritually instead of controlling them. Spiritual intelligence is the ability to act with wisdom and compassion while maintaining inner and outer peace (Wigglesworth, 2012). It is a crucial component of authentic leadership necessary to cope with disruptive changes in the digital world (Fig 5). The integration of spiritual intelligence (SQ) with rational intelligence (IQ) and emotional intelligence (EQ) will help the leader to maintain his inner balance, which forms the foundation for a grace-based leadership model.

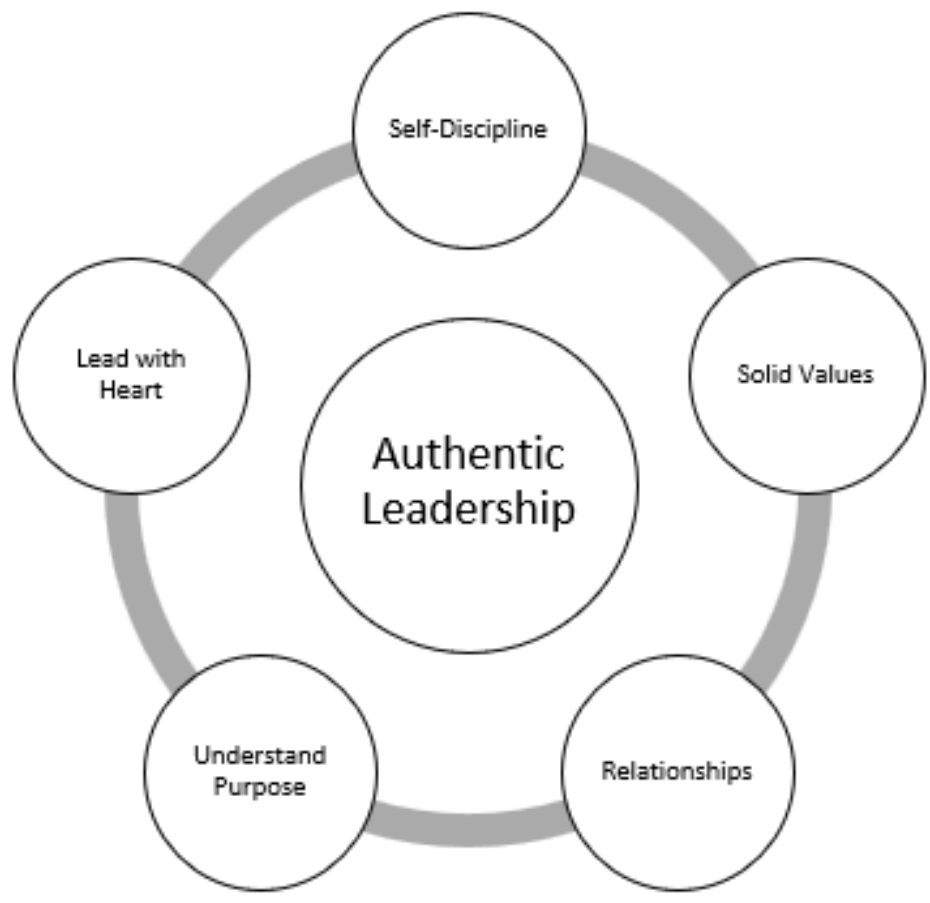

Figure 5. Authentic Leadership 


\section{Methodology}

This study uses both interpretative phenomenological and hermeneutics approaches to interpret and understand the divine and classical texts of I Ching, Confucian Analects, Sutras, Quran, and Bhagavad Gita. Qualitative methods are preferred for humanities research as a means to explore human opinions and perceptions through the first-hand experience. The author attempts to develop an understanding of the phenomena under study, based on his experience as a senior business leader and from the scholarly research literature. Elliott (1995) argued that the central purpose of qualitative research is to contribute to a process of revision and enrichment of understanding, rather than to verify earlier theories.

Phenomenology emphasizes the subjective experiences and interpretations of the world as we can only know how things appear to us and to others and not how they really are. Phenomenology and hermeneutics are closely linked. The phenomenologists focus on the lived experience of persons eliciting commonalities and shared meanings, while hermeneutics relates to the interpretation of text and language. Phenomenology is a form of inquiry that seeks to understand human experience and to explore how the phenomena are perceived and experienced by the individual (Moustakas, 1994; Lester 1999).

Interpretative phenomenology developed by Jonathan Smith in the mid-1900s explores in detail how participants are making sense of their personal and social world. It is concerned with an individual's perception or account of an object or event, as opposed to an attempt to produce an objective statement of the object itself. The main insight of phenomenology is the intentionality of consciousness. Every conscious act intends something. If the act is present, the object is also present. In interpretative approach, the researcher embarks on studying by immersing himself in the world of participants through a lens of cultural and sociohistorical meanings (Moran, 2000; Smith 2004).

Hermeneutics is selected as an appropriate research approach since the objective is to use an interpretive approach to study judgment artistry of managerial practices. A review of the sacred Sutra, Quran, and Bhagavad Gita hermeneutics together with the interpretation of I Ching and Confucian Analects was taken to establish a common thread, namely humanism, to build upon a model for grace-based leadership. In hermeneutics research, the emphasis is on the subjective interpretations in the meaning of texts, culture, social phenomenon, and thinking. Variations of hermeneutics philosophy and methodologies have been developed moving beyond the illumination of the biblical text to the illumination of human understanding, including the cultural systems and organizations (Scheiermacher, 1977; Dithey, 1988). The hermeneutic approach theorises that the most basic fact of social life is the meaning of an action. Social life is determined by social actions, and actions are oriented towards the meanings of prior actions.

The integrative nature of hermeneutic understanding occurs only when the interpreter recognizes the significance of the various items that he notices and recognizes the relationships between the various variables (Bontekoe, 1996). Creative interpretation of the words and text will bring the research new insights to leadership practices. To understand the text means to apply it and to know that even if it is understood in different ways, it is still the same text (Gadamer, 1996). As such, researchers who adopt a hermeneutics approach embraces ambiguity as the norm. This is in line with the concept of leadership as it is not straightforward nor easily defined.

Ensuring quality is important in hermeneutic research. Quality relates to credibility, rigor, and ethical behavior (Paterson and Higgs, 2005). Credibility relates to the truth and value of the findings (Leninger, 1994). The process of hermeneutic analysis must involve a critique of existing leadership models and the need to consider a new paradigmatic framework that addresses the relationship between the research topic and approach. Rigor refers to the deep immersion in the texts and making sense of the phenomenon in relation to the texts. Ethical consideration could be enhanced by representing the material and findings with transparency, honesty, and trust, without manipulation of the texts. This interpretive approach enables the author to examine complex human phenomena from multiple perspectives to produce rich theoretical interpretations of leadership behaviors.

\section{Discussion}

Effective leaders are able to nurture the talents of their followers. They act as change agents for their organizations. Their rationale, emotional, and spiritual intelligence may not be enough to guide them through the complexities of the business world. Very often, their failure is the result of the imbalances between the 
ISSN (online) - 2520-6311; ISSN (print) - 2520-6761

three intelligences: SQ, IQ, and EQ. The leader who seeks power over people instead of collaborating with them misuses his position of power and trust. His quest for power overtakes his development of inner peace and relationship with others. He seeks self-aggrandisation at the expense of organizational goals. The ideal situation most organizations hope to achieve includes having employees who are highly engaged and committed, a culture of high ethics, and a workplace which respects diversity and inclusivity. In reality, many of them fall short of the ideal.

Authentic leaders are supposed to be aware of how they think and behave and are perceived by others as being aware of their own values and moral perspectives. However, most leaders display a combination of authentic and inauthentic behaviors in them as they use their position to feed their narcissism and need for power. While they possess the social competence to manage the relationship, they are less empathetic to the needs of their employees. They may have a compelling vision for the organization, but they have lost the grace of leadership.

A grace-based leadership approach calls for one to develop his inner-self regardless of how he sees himself or how others perceive him. A central idea in grace-based leadership is God's grace in the Christian faith. It embraces the principles of humanism and recognizes that leaders are not perfect. They may have succumbed to their narcissism and ego. They may have indulged in power and office politics and justified their actions as the way to move the organization forward. They may also have masqueraded as victims of a narcissist only to garner support to silence the voice of their opponents.

Leaders who practice grace-based style leadership acknowledge that they have made mistakes in the past, are inadequate in many ways and are willing to commit to doing things right. They are able to inspire their followers to offer their full commitment and create a cycle of ever-improving morale within the organization. The golden rule is to treat others the way we want others to treat us. It is a leadership style centered on understanding, forgiving, and encouraging others (Fig. 6).

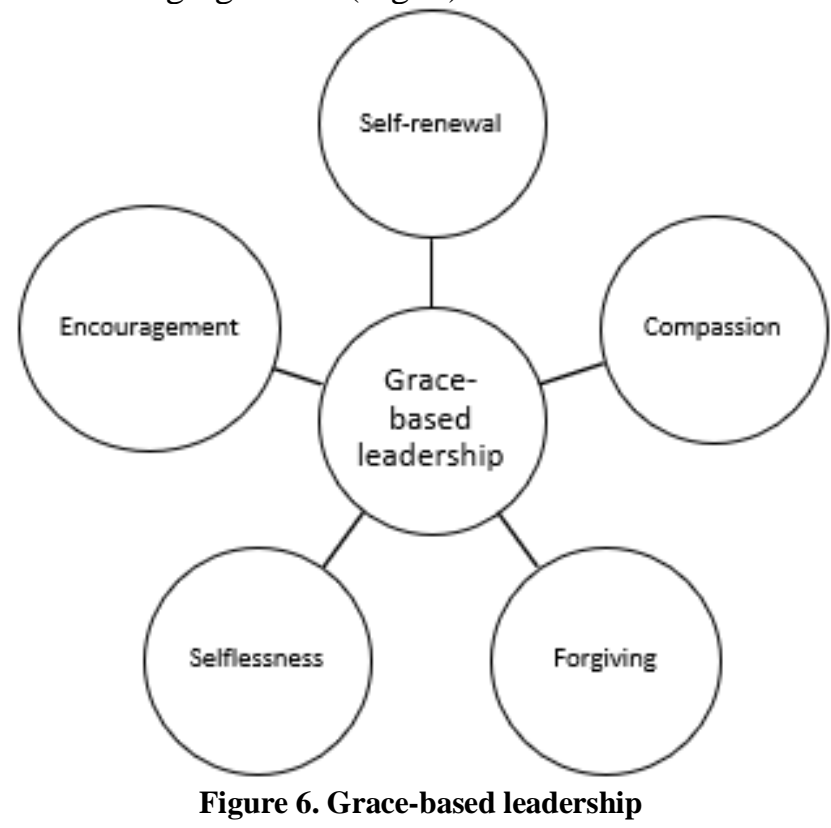

Source: Elaborated by the author

The grace-based leadership model can be embraced by organizations as an overarching guide for their leaders to follow. The religious aspect of it has been deemphasized but the idea behind changing the hearts rather than merely modifying behavior or accomplishing tasks is the antidote to many leadership failures. Those who wish to move their leadership competencies to a higher level should embrace an inner journey of self-renewal and make an outer commitment to advance the common good of the community. Leaders who secure their position through exerting fear to control others are a liability to their organizations. In contrast, grace-based leaders are able to contribute to the eudaemonic well-being of followers and themselves (Huta and Waterman, 2004).

\section{Conclusion}

The concept of Gen $A$ is introduced to highlight the contribution of competent employees regardless of whether they are Baby Boomers, Gen X, Gen Y, or Gen Z. Organizations should not discriminate individuals 
based on their age, especially those baby boomers who have a wealth of experience which they could bring to the workplace. Diversity and inclusion are important as they improve employees' morale which directly impacts their performance. A variety of skills and experiences among the team members enables employees to learn from each other. Effective leaders should create and maintain a positive work environment where diversity is valued so that employees can maximize their potential and contribute to the organization's goals.

One can never be a perfect leader without practicing grace-based leadership. While Level 5 leadership focuses on humility, relationship building, and the will of a leader, a grace-based leader is one who is capable of changing followers hearts and not just their behaviors. Grace-based leadership can be considered a post-Level 5 or Level 6 concept. A grace-based leader willingly learns from his mistakes rather than blaming his subordinates. He realizes his own limitations and understands the need to value people, winning their hearts as well as their loyalty. This approach is an important philosophy in leading Gen A as it recognizes the importance of social needs of the individual and expands the traditional motivational concepts beyond tangible and economic factors. It places the dignity of the individual over profit to make the business more sustainable. Ethical practices are a norm and are strongly embedded in the corporate culture. Organizations must take the human perspective over the technology perspective to drive effective customers' experience and employees' motivation. The deciding factor for an organization's success in the digital era will be its ability to evolve its corporate culture to not only take advantage of emerging technologies but also to embrace the principle of humanism in the workplace. The mindset of leaders must change to embrace a grace-based leadership approach to managing Gen A.

\section{References}

1. Aabed, A. I. (2006). Study of Islamic Leadership Theory and Practice in K-12 Islamic School in Michigan. (Doctoral dissertation, Brigham Young University, USA). Retrieved from: http://scholarsarchive.byu.edu/etd/408/.

2. Alvarez, J.L. \& Svejenova, S. (2005). Sharing executive power: Roles and relationships at the top. Cambridge: Cambridge University Press.

3. Barile, S., and Polese, F. (2010). Linking the viable system and manyto-many network approaches to service-dominant logic and service science. International Journal of Quality and Service Science, 2(1), 23-42.

4. Bartlett, C. A. and Ghoshal, S. (1994). Changing the Role of Top Management: From Strategy to Purpose. Harvard Business Review 72(3), 79-88.

5. Bontekoe, R. (1996). Dimensions of the hermeneutic circle. Atlantic Highlands, NJ: Humanities Press.

6. Dilthey, W. (1988). Introduction to the human science: An attempt to lay a foundation for the study of society and history (R. J. Betzanos, Trans.). Detroit, MI: Wayne State University Press.

7. Elliott, R. (1995). Therapy process research and clinical practice: Practical strategies. In M. Aveline \& D. A. Shapiro (Eds), Research foundations for psychotherapy practice, pp. 49-72. Chichester: Wiley.

8. Fournier, S., Avery, J. (2011). Uninvited brand. Business Horizons, 54, 193-207.

9. Gadamer, H.G. (1996). Truth and method (2nd rev. ed., Joel Weinsheimer \& Donald Marshall, Trans.). New York: Continuum.

10.Golinelli, G.M., Pastore, A., Gatti, M., Massaroni, E., Vagnani, G. (2002). The firm as a viable system: managing inter-organisational relationships. Sinergie, 58, 65-98.

11.Hurley, M. (1972). Ethical Problems of the Association Executive, in Study Guide for Institutes of Organizational Management, Chamber of Commerce of the United States, Washington, DC, 2.

12.Huta, V., \& Waterman, A. S. (2014). Eudaimonia and its distinction from hedonia: Developing a classification and terminology for understanding conceptual and operational definitions. Journal of Happiness Studies, 15, 1425-1456.

13.Khong, K. W., Onyemeh, N. C., \& Chong, A. Y. L. (2013). BSEM estimation of network effect and customer orientation empowerment on trust in social media and network environment. Expert Systems with Applications, 40(12), 4858-4870.

14.Leininger, M. M. (1994). Evaluation criteria and critique of qualitative research studies. In J. Morse (Ed.), Critical issues in qualitative research methods (pp. 163-188). Thousand Oaks, CA: Sage.

15.Lester, S. (1999). An introduction to phenomenological research. Taunton UK, Stan Lester Developments. Retrieved from: http://www.sld.demon.co.uk/resmethy.pdf.

16.Luthra, A., and Dahiya, R. (2015). Effective Leadership is all about communicating effectively: Connecting Leadership and Communication. International Journal of Management and Business Studies, $5(3), 43-48$. 
Business Ethics and Leadership, Volume 3, Issue 3, 2019

ISSN (online) - 2520-6311; ISSN (print) - 2520-6761

17.Moran, D. (2000). Introduction to phenomenology. Routledge, London.

18.Moustakas, C. (1994). Phenomenological research methods. Thousand Oaks: Sage Publications.

19.Paterson, M. and Higgs, J. (2005). Using hermeneutics as a qualitative research approach in professional practice. The Quality Report, 10(2), 339-357.

20.Peters, L. and Manz, C. (2007). Identifying antecedents of virtual team collaboration. Team Performance Management, 13(3/4), 117-129. Available at: https://doi.org/10.1108/13527590710759865.

21.Poell, R. F., Tijmensen, E. C. M. \& Van der Krogt, F. J. (1997). Can learning projects contribute to develop a learning organisation? Lifelong Learning in Europe, 2(2), 67-75.

22.Schleiermacher, F. (1977). Hermeneutics: The handwritten manuscripts (J. Drake \& J. Forstman, Trans.). Missoula, MT: Scholars Press.

23.Senge, P.M. (2006). The fifth discipline: The art and practice of the learning organization. Toronto.: Doubleday.

24.Smith, J.A. (2004). Reflecting on the development of interpretative phenomenological analysis and its contribution to qualitative research in psychology. Qualitative Research in Psychology, 1(1), 39-54.

25.Wigglesworth, Cindy (2012). The twenty-one skills of spiritual intelligence. New York, NY: Selectbooks. 26.Yu, S.O. (2019). Humanising Gen A Leadership: Inspiration from I Ching. Freemantle, WA: Fontaine. 